\title{
Pengaruh Pemberian Bahan Humat dan Pupuk SP-36 untuk Meningkatkan Ketersediaan Fosfor pada Tanah Ultisol
}

The Influence of Humic Matter and Phosforus Fertilizer for Increasing Available P in Ultisol

\section{Mutia Lisdiyanti, Sarifuddin*, Hardy Guchi}

Program Studi Agroteknologi, Fakultas Pertanian USU Medan 20155

*Corresponding Author: Sarif2000@yahoo.com

\begin{abstract}
The aim of the research is to know the influence of humic matter and phosforus fertilizer for increasing available $P$ in ultisol. The experiment consists of 2 factors with 2 replications using randomized block design. The first factor was humic material with 4 treatments $(0,400$, 800 , and $1200 \mathrm{ppm})$ and the second factor was phosforus fertilizer with 4 treatments $(100 \%$, $75 \%, 50 \%$, and $0 \%$ dosages). The result showed that application of humic matter increasing pH, P-available, and decreased Al-exch with the best dosage is 800 ppm humic matter and application of phosforus fertilizer increasing $\mathrm{pH}$, P-available, dry weight of root and sloot, $P$-leaf and decreased Al-exch with the best dosage is 75\% dosage. Interaction between humic matter and phosforus fertilizer not affected to all parameters

Keywords: Ultisol, P Fertilizer, Humic matter
\end{abstract}

\begin{abstract}
ABSTRAK
Penelitian ini bertujuan untuk mengetahui pengaruh pemberian bahan humat dan pupuk $\mathrm{P}$ untuk meningkatkan ketersedian $\mathrm{P}$ di tanah ultisol. Penelitian ini terdiri dari 2 faktor perlakuan dan 2 ulangan. Faktor pertama bahan humat dengan 4 perlakuan $(0,400,800$, dan $1200 \mathrm{ppm})$ dan faktor kedua pupuk $\mathrm{P}$ terdiri dari 4 perlakuan $(100 \%, 75 \%, 50 \%$, dan 0\% rekomendasi). Hasil penelitian ini menunjukan bahwa pemberian bahan humat meningkatkan $\mathrm{pH}$, P-tersedia, dan menurunkan Al-dd dengan dosis terbaik $800 \mathrm{ppm}$ bahan humat dan pemberian pupuk $\mathrm{P}$ meningkatkan $\mathrm{pH}, \mathrm{P}$-tersedia, bobot kering akar dan tajuk, $\mathrm{P}$-daun dan menurunkan Aldd dengan dosis terbaik $75 \%$ rekomendasi. Interaksi antara bahan humat dan pupuk $\mathrm{P}$ menunjukan pengaruh tidak nyata terhadap semua parameter yang diamati.
\end{abstract}

Kata Kunci : Ultisol, Pupuk P, Bahan Humat

\section{PENDAHULUAN}

Sifat kimia Ultisol yang paling dominan adalah reaksi tanah yang masam, disebabkan oleh pengaruh Aluminium (Al) dalam larutan tanah yang cenderung terhidrolisis menjadi Al-hidroksida $\left(\mathrm{Al}(\mathrm{OH})_{3}\right)$. Dalam proses tersebut membebaskan sejumlah ion hidrogen ke dalam larutan tanah sehingga tanah bereaksi masam (Brady, 1990).
Humus merupakan hasil perombakan bahan organikyang memegang peranan penting pada sifat tanah. Humus merupakan suatu campuran komplek yang relatip resisten, bersifat koloidal dan berasal dari dekomposisi dan sintesis mikroba serta mempunyai sifat fisik yang sangat berpengaruh terhadap tanah dan tanaman. Fraksi terhumifikasi dari humus disebut sebagai senyawa humat (Brady, 1990). 
Bahan humat (asam humat dan fulvat) merupakan hasil akhir dari proses dekomposisi bahan organik, dan paling aktif karena mempunyai gugus karboksil $(-\mathrm{COOH})$ dan fenolik $(-\mathrm{OH})$ yang diketahui berperan dalam penyediaan unsur fosfor melalui reaksi khelasi dengan mengkhelat kationkation logam yang berlebih, sehingga aktivitas logam $\mathrm{Al}$ dan $\mathrm{Fe}$ yang biasanya mengikat $\mathrm{P}$ dapat berkurang dan tidak meracun bagi tanaman (Tan, 2010). Kelarutan logam seperti $\mathrm{Al}, \mathrm{Fe}$, dan Mn yang sangat tinggi akan menyebabkan unsur hara makro seperti fosfor $(\mathrm{P})$ menjadi tidak tersedia bagi tanah (Damanik, et al. 2011).

Bahan humat memiliki beberapa molekul dan ukuran, mulai dari beberapa ratus hingga beberapa ratus ribu unit massa atom. Bahan humat terdiri dari asam humat, asam fulvat, dan humin. Secara umum asam fulvat memiliki berat molekul lebih rendah dari asam humat. Bahan humat memiliki komposisi bervariasi tergantung pada sumbernya, lokasi, metode ekstraksi. Namun kesamaan mereka lebih nyata dan jelas daripada perbedaan mereka. Kisaran komposisi unsur bahan humat relatip sempit, sekitar 40-60\% karbon, 30-50\% oksigen, 4-nitrogen, 1-2\% sulfur, dan $0,03 \%$ fosfor. Asam humat mengandung lebih banyak hidrogen, karbon, nitrogen, dan sulfur tetapi kandungan oksigennya lebih sedikit dibandingkan asam fulvat. Humin menunjukan kemiripan dengan asam humat tetapi humin terikat dengan logam dan liat, sehingga membuat humin tidak larut (Kumada, 1987).

Menurut Schnitzer dan Khan (1978) salah satu karakteristik yang paling khas dari senyawa humat adalah kemmapuannya berinteraksi dengan ion logam, oksida, hidroksida, mineral, dan organic, termasuk zat pencemar lainnya. Sejumlah senyawa organik dalam tanah mampu mengikat ion-ion logam yang berlebih, sehingga jumlahnya menjadi lebih sedikit dalam larutan tanah sebagaimana dibutuhkan tanaman.

Fosfor merupakan unsur hara essensial. Tidak ada unsur lain yang dapat mengganti fungsinya di dalam tanaman, sehingga tanaman harus mendapatkan atau mengandung P secara cukup untuk pertumbuhannya secara normal. Oleh karena $\mathrm{P}$ dibutuhkan tanaman cukup. Fungsi penting fosfor dalam tanaman yaitu dalam proses fotosintesis, respirasi, transfer dan penyimpanan energi, pembelahan dan pembesaran sel serta proses-proses di dalam tanaman lainnya dan membantu mempercepat perkembangan akar dan perkecembahan. $\mathrm{P}$ dapat merangsang pertumbuhan akar, yang selanjutnya berpengaruh pada pertumbuhan bagian di atas tanah (Winarso, 2005).

Fosfor (P) termasuk hara esensial bagi tanaman dengan fungsi sebagai pemindah energi, yang tidak dapat digantikan dengan hara lain. Ketidakcukupan pasok $\mathrm{P}$ menyebabkan tanaman tidak tumbuh maksimum. Peranan fosfor dalam penyimpanan dan pemindahan energi tampaknya merupakan fungsi terpenting pada tanaman (Mas'ud, 1993).

Pada penelitian Jeni (2014) penggunaan bahan humat yang berasal dari ekstrak gambut berkadar $10 \%$ bahan humat yang diinkubasi selama 2 minggu pada tanah inceptisol mampu meningkatkan $\mathrm{pH}$ tanah menjadi 4,74 pada perlakuan dengan dosis $1000 \mathrm{ppm}$, tetapi tidak berpengaruh nyata terhadap status P-tersedia dan Al-dd. 


\section{BAHAN DAN METODE}

Penelitian ini dilaksanakan di Rumah Kasa Fakultas Pertanian Universitas Sumatera Utara. Penelitian ini dilaksanakan mulai bulan Juni 2017 sampai dengan November 2017 dan analisis tanah di Laboratorium Kimia Kesuburan Fakultas Pertanian Universitas Sumatera Utara.

Bahan yang digunakan untuk penelitian ini adalah contoh tanah Ultisol Galang yang diambil pada kedalaman $0-20 \mathrm{~cm}$ secara komposit, bahan humat yang dibeli di PT. Humat Indonesia, pupuk SP-36, benih jagung, air aquadest dan bahan-bahan kimia yang digunakan untuk keperluan analisis tanah

Alat yang digunakan untuk penilitian ini adalah cangkul, goni, kantong plastik, polybag, timbangan, kertas label, plastik label, dan alat-alat laboratorium lainnya untuk keperluan analisis tanah.

Penelitian ini menggunakan Rancangan Acak Kelompok (RAK) factorial dengan 2 faktor perlakuan dan 2 ulangan yaitu : faktor satu merupakan dosis bahan humat terdiri dari H0 (0 ppm), H1 (400 ppm (20 ml / $10 \mathrm{~kg}$ tanah)), H2 (800 ppm(40 ml / $10 \mathrm{~kg}$ tanah)), dan H3 (1200 ppm(60 ml / 10 $\mathrm{kg}$ tanah)) dan faktor dua merupakan dosis pupuk SP-36 terdiri dari P0 (0 gr), P1 (2,4 gr / polybag), P2 (3,6 gr / polybag), dan P3 ( 4,8 gr / polybag).

Masing-masing perlakuan disusun sebanyak 2 ulangan sehingga diperoleh unit percobaan 32 unit percobaan.

Selanjutnya data dianalisis dengan ANOVA (Analysis of Variance) pada setiapparameter yang diukur. Uji lanjutan dilakukan bagi perlakuan yang nyata denganmenggunakan Uji DMRT (Duncan Multiple Range Test).

\section{HASIL DAN PEMBAHASAN}

Hasil analisis sidik ragam menunujukkan bahwa $\mathrm{pH}$ Tanah, Al-dd Tanah, P-tersedia, yang berpengaruh nyata akibat pemberian bahan humat. Hasil uji beda rataan terhadap parameter tanah dapat dilihat pada Tabel 1 .

Hasil analisis sidik ragam bahwa pH tanah, Al-dd, P-tersedia, berat kering akar, berat kering tajuk, serapan $\mathrm{P}$, dan $\mathrm{P}$-daun yang berpengaruh nyata akibat pemberian pupuk SP-36. Hasil uji beda rataan terhadap parameter tanah yang dapat dilihat pada tabel 2 .

\section{pH dan Al-dd}

Dari Tabel 1 dapat diketahui bahwa $\mathrm{pH}$ dan Al-dd tanah pada masa akhir masa inkubasi tanah dan $\mathrm{pH}$ dan Al-dd tanah pada akhir masa vegetatife tanaman tertinggi terdapat pada perlakuan $\mathrm{H} 2$ dan terendah pada perlakuan H0. Peningkatan $\mathrm{pH}$ tanah dan penurun Al-dd tanah akibat pemberian bahan humat disebabkan oleh muatan negatif dan gugus fungsional bahan humat (gugus karboksil $\left(\mathrm{COO}^{-}\right)$dan fenolat $\left.\left(\mathrm{OH}^{-}\right)\right)$ membentuk senyawa kompleks atau khelat Al sehingga sebagian Al tidak dapat terhidrolisis. Apabila Al tidak terhidrolisis maka ion hidrogen penyebab kemasaman tanah pun berkurang, akibatnya $\mathrm{pH}$ tanah menjadi naik dan Al-dd mengalami penurunan. Tan (2010) menyatakan bahwa Al- yang terjerap oleh kompleks liat dapat terhidrolisis dan mengahasilkan ion hidrogen sehingga konsentrasi ion tersebut meningkat didalam tanah yang menyebabkan $\mathrm{pH}$ menjadi masam. Dengan terbentuknya komplek antara Al dan asam-asam organikmaka reaksi hidrolisis $\mathrm{Al}$ dapat dihalangi. 
Tabel. 1. Nilai rataan $\mathrm{pH}, \mathrm{Al}$-dd, dan P-tersedia tanah akibat pemberian bahan humat

\begin{tabular}{cccccc}
\hline \multirow{2}{*}{ Perlakuan } & \multicolumn{1}{c}{$\mathrm{pH}^{*}$} & $\mathrm{pH} \#$ & $\mathrm{Al}-\mathrm{dd} *$ & $\mathrm{Al}-\mathrm{dd} \#$ & P-tersedia \\
\cline { 2 - 6 } & ----- & --- & $\mathrm{me} / 100 \mathrm{~g}$ & $\mathrm{me} / 100 \mathrm{~g}$ & $\mathrm{ppm}$ \\
\hline $\mathrm{H} 0$ & $5,58 \mathrm{~b}$ & $5,28 \mathrm{a}$ & $5,01 \mathrm{~b}$ & $0,53 \mathrm{a}$ & $6,61 \mathrm{~b}$ \\
$\mathrm{H} 1$ & $5,77 \mathrm{ab}$ & $5,44 \mathrm{ab}$ & $5,55 \mathrm{a}$ & $0,51 \mathrm{a}$ & $9,87 \mathrm{a}$ \\
$\mathrm{H} 2$ & $5,92 \mathrm{a}$ & $5,69 \mathrm{a}$ & $5,71 \mathrm{a}$ & $0,37 \mathrm{~b}$ & $10,07 \mathrm{a}$ \\
$\mathrm{H} 3$ & $5,83 \mathrm{a}$ & $5,49 \mathrm{ab}$ & $5,63 \mathrm{a}$ & $0,51 \mathrm{a}$ & $6,81 \mathrm{~b}$ \\
\hline
\end{tabular}

* : Akhir masa inkubasi tanah

\# : Akhir masa vegetatif tanaman

Tabel. 2. Nilai rataan $\mathrm{pH}, \mathrm{Al}-\mathrm{dd}, \mathrm{P}$-tersedia, berat kering akar, berat kering tajuk, Serapan $\mathrm{P}$, dan $\mathrm{P}$-daun akibat pemberian pupuk SP-36

\begin{tabular}{cccccccccc}
\hline Perlakuan & $\mathrm{pH}^{*}$ & $\mathrm{pH} \#$ & $\mathrm{Al}-\mathrm{dd} *$ & $\mathrm{Al}-\mathrm{dd} \#$ & P-tersedia & $\mathrm{BKA}$ & $\mathrm{BKT}$ & Serapan P & P-daun \\
\cline { 2 - 9 } & ----- & ---- & $\mathrm{Me} / 100 \mathrm{~g}$ & $\mathrm{Me} / 100 \mathrm{~g}$ & $\mathrm{ppm}$ & $\mathrm{gr}$ & gr & mg/tanaman & mg/tanaman \\
\hline P0 & $5,01 \mathrm{~b}$ & $5,14 \mathrm{c}$ & $0,73 \mathrm{a}$ & $0,66 \mathrm{a}$ & $3.32 \mathrm{c}$ & $0,98 \mathrm{~b}$ & $0,98 \mathrm{~b}$ & $0,98 \mathrm{~b}$ & $0,04063 \mathrm{~b}$ \\
P1 & $5,55 \mathrm{a}$ & $5,88 \mathrm{~b}$ & $0,59 \mathrm{~b}$ & $0,43 \mathrm{ab}$ & $8.18 \mathrm{~b}$ & $5,58 \mathrm{a}$ & $5,58 \mathrm{a}$ & $5,58 \mathrm{a}$ & $0,10038 \mathrm{a}$ \\
P2 & $5,71 \mathrm{a}$ & $6,13 \mathrm{a}$ & $0,55 \mathrm{~b}$ & $0,41 \mathrm{~b}$ & $11.38 \mathrm{a}$ & $6,93 \mathrm{a}$ & $6,93 \mathrm{a}$ & $6,93 \mathrm{a}$ & $0,10063 \mathrm{a}$ \\
P3 & $5,63 \mathrm{a}$ & $5,95 \mathrm{ab}$ & $0,60 \mathrm{~b}$ & $0,42 \mathrm{~b}$ & $10.49 \mathrm{ab}$ & $7,18 \mathrm{a}$ & $7,18 \mathrm{a}$ & $7,18 \mathrm{a}$ & $0,10188 \mathrm{a}$ \\
\hline
\end{tabular}

* : Akhir masa inkubasi tanah

\# : Akhir masa vegetatif tanaman

Dari tabel 2 dapat diketahui bahwa $\mathrm{pH}$ dan $\mathrm{Al}$-dd tanah pada masa akhir masa inkubasi tanah dan $\mathrm{pH}$ dan Al-dd tanah pada akhir masa vegetatife tanaman tertinggi terdapat pada perlakuan P2 dan terendah pada perlakuan P0. Hal ini disebabkan kandungan $\mathrm{Ca}^{2+}$ pada pupuk SP-36 yang akan melakukan reaksi pertukaran dengan kation $\mathrm{H}^{+}$dan $\mathrm{Al}^{3+}$ yang teradsorpsi dipermukaan koloid tanah sehingga $\mathrm{pH}$ meningkat apabila $\mathrm{pH}$ meningkat maka $\mathrm{Al}$ didalam tanah juga rendah. Hal ini sesuai dengan Bruckman and Brady (1982) Pengaruh pupuk $\mathrm{P}$ terhadap peningkatanpH tanah karena adanya pelepasansejumlah $\mathrm{OH}^{-} \mathrm{ke}$ dalam larutan akibatadsorpsi sebagian anion fosfat $\left(\mathrm{H}_{2} \mathrm{PO}_{4}{ }^{-}\right)$olehoksida-hidrat $\mathrm{Al}$ dan Fe sehingga $\mathrm{pH}$ tanahmeningkat.

\section{P-tersedia}

Dari tabel 1 dengan pemberian bahan humat dengan takaran 800 ppm (H2) mampu meningkatkan P-tersedia sebesar 3,46 ppm bila dibandingkan dnegan tanpa pemberian bahan humat (H0). Ketersediaan $\mathrm{P}$ tanah meningkat seiring dengan peningkatan $\mathrm{pH}$ dan menurunnya Al-dd tanah. Stevenson (1994) mengemukakan bahwa bahan humat berperan dalam mengatasi pengikatan $\mathrm{P}$ yaitu dengan mencegah terjadinya interaksi logam $\mathrm{Al}$ dan $\mathrm{Fe}$ dengan ion $\mathrm{P}$ melalui reaksi kompleks dan khelat. Hervianti et.al (2012) dalam penelitiannya juga menyatakan bahwa bahan humat mempunyai peran dalam pelepasan $\mathrm{P}$ yang terjerap dalam tanah serta akan meningkatkan ketersediaan $\mathrm{P}$ didalam tanah.

Dari tabel 2 pengaruh SP-36 dalam ketersediaan $\mathrm{P}$ ditanah ultisol 
menunjukan pengaruh yang nyata. Pada taraf perlakuan $112,5 \mathrm{~kg} \quad \mathrm{P}_{2} \mathrm{O}_{5} / \mathrm{ha}(\mathrm{P} 2)$ meningkatkan P-tersedia tanah sebesar 8,06 ppm bila dibandingkan dengan perlakuan kontrol (P0). Kenaikan Ptersedia tanah disebabkan oleh pengaruh langsung dari pupuk fosfor tersebut dikarenakan pemupukan fosfor meningkatkan kadar P-tersedia dalam tanah atau melalui mekanisme pelepasan fosfor dari kompleks adsorbsi. Hal ini sesuai literatur Winarso (2005) peningkatan kandungan P-tersedia tanah jelas disebabkan oleh pengaruh langsung dari pupuk $\mathrm{P}$ sebab pemupukan fosfat meningkatkan kadar P-tersedia dalam tanah atau melalui mekanisme pelepasan $\mathrm{P}$ dari kompleks adsorpsi.

Interaksi bahan humat dan pupuk SP-36 tidak ada pengaruh langsung dalam meningkatkan ketersedian P ditanah. Pemberian bahan humat dan SP-36 tidak memberikan respon yang baik. Hal ini dikarenakan bahan humat tidak mengandung unsur $\mathrm{P}$ namun dapat mengkhelat $\mathrm{Al}$ sehingga tidak terjadi fiksasi $\mathrm{P}$ dan bahan humat mempercepat kelarutan $\mathrm{P}$.

\section{Berat Kering Akar}

Dari tabel 2 dengan pemberian pupuk SP-36 berpengaruh nyata terhadap bobot kering akar tanaman dengan perlakuan terbaik pada perlakuan P3. Hal ini disebabkan pupuk SP-36 yang ditambahkan kedalam tanah dapat diambil tanaman karena pengikatan $\mathrm{P}$ oleh $\mathrm{Al}$ semakin berkurang sejalan dengan berkurangnya kadar Al-dd tanah dan meningkatnya Ptersedia tanah. Disamping itu dengan berkurangnya kadar Al tanah, akan memberikan peluang bagi akar untuk berkembang lebih baik. Hardjowigeno (2003) menyatakan unsur fosfor sangat berguna untuk merangsang pertumbuhan dan perkembangan akar, bahan dasar protein, proses fotosintesis, memperkuat batang tanaman serta membantu asimilasi dan respirasi.

\section{Berat Kering Tajuk}

Pemberian pupuk SP-36 berpengaruh nyata terhadap berat kering tajuk tanaman terlihat titik optimum terjadi pada perlakuan P2 namun pada perlakuan P3 mengalami penurunan kembali. Hal ini menunjukan bahwa pemberian pupuk $\mathrm{P}$ yang berlebih (diatas kebutuhan optimum), akan menyebabkan kenaikan hasil yang semakin berkurang dan bahkan apabil terlalu berlebihan akan mengalami toksik bagi tanaman.

\section{P-daun dan Serapan $\mathbf{P}$}

Pemberian pupuk SP-36 berpengaruh dalam meningkatkan P-daun tanaman. Semakin besar konsentrasi yang diberikan ke tanah semakin meningkat pula P-daun tanaman tersebut. Meningkatnya P-daun tanaman berpengaruh dalam serapan $\mathrm{P}$ tanaman. Serapan $\mathrm{P}$ yang tinggi menyebabkan pendewasaan tanaman lebih cepat sehingga akan merangsang laju pertumbuhan vegetatif tanaman. Hal ini berpengaruh terhadap berat kering akar dan tajuk yang tidak berkembang secara maksimal dikarenakan tanaman mengalami pendewasaan terlalu cepat.

$$
\text { Pemberian Pupuk SP-36 }
$$

berpengaruh nyata terhadap serapan $\mathrm{P}$ tanaman. Terjadinya peningkatan Serapan-P bila diberi pupuk fosfat disebabkan oleh adanya ketersediaan fosfor tanah yang meningkat akibat pemberian pupuk P. Dengan meningkatnya P-tersedia tanah dan memanjangnya akar maka kontak secara 
difusi antara akar tanaman dan $\mathrm{P}$ yang ada dalam tanah menjadi lebih besar sehingga akar tanaman dan P yang ada dalam tanah menjadi lebih besar

\section{SIMPULAN}

Pemberian bahan humat meningkatkan $\mathrm{pH}, \quad$ P-tersedia, dan menurunkan Al-dd tanah tetapi bahan humat tidak meningkatkan berat kering akar, berat kering tajuk dan serapan P.

Pemupukan SP-36 meningkatkan ketersediaan $\mathrm{pH}, \mathrm{P}$-tersedia, berat kering akar, berat kering tajuk, serapan $\mathrm{P}$ dan menurunkan Al-dd tanah.

Interaksi perlakuan bahan humat dan pupuk SP-36 tidak meningkatkan ketersediaan $\mathrm{pH}, \quad$ P-tersedia, berat kering akar, berat kering tajuk, serapan $\mathrm{P}$ dan menurunkan Al-dd tanah.

\section{DAFTAR PUSTAKA}

Brady, N. C., 1990. The Nature and Properties of Soil. $10^{\text {th }}$ ed. MacMillan Publishing Co. New York.

Bruckman, H. O. dan N.C. Brady, 1982. Ilmu Tanah . Terjemahan Soegiman. Bharata Karya Aksara, Jakarta.

Damanik, M. M. B. B. E. Hasibuan, Fauzi, Sarifuddin, dan $\mathrm{H}$. Hanum. 2011. Kesuburan Tanah danPemupukan. USU Press. Medan.

Hardjowigeno, S. 2003. Ilmu tanah. Jakarta. Akademi Pressindo. 286 hal.

Herviyanti, Ahmad F, Sofyani R, Darmawan, Gusnidar, Saidi A. 2012. Pengaruh pemberian bahan humat dari ekstrak batubara muda (subbituminus) dan pupuk $\mathrm{P}$ terhadap sifat kimia Ultisol serta produksi tanaman sehingga lebih banyak $\mathrm{P}$ yang diambil atau diserap oleh tanaman.

jagung (Zea mays L.). $J$ Solum. 9(1):15-24.

Jeni, S. 2014. Perubahan Sifat Kimia Inceptisol Melalui Aplikasi Bahan Humat Ekstrak Gambut Dengan Inkubasi Dua Minggu. Fakultas Pertanian. Universitas Sumatera Utara. Medan.

Kumada, Kyoichi. 1987. Chemistry of Soil Organic Matter. Japan. Japan Scientific Societies Press, Tokyo.

Mas'ud, P. 1993. Telaah Kesuburan Tanah. Angkasa. Bandung.

Rao, S. 1982. Advances in Agricultural Microbiology Oxford and IBH. Publishing Co. New Delhi. Bombai. Calcuta.

Schnitzer and S. U. Khan. 1978. Soil Organic Matter. Elsevier Sci. Publ. Amsterdam.

Soil Survey Staff. 2014. Keys To Soil Taxonomy. Eleventh Edition. 2014. United States Departement of AgricultureNatural Resources Conservation Service. Washington, DC

Stevenson, F.J. 1994. Нumus

Chemistry, Genesis,

Composition, and

Reactions.John Wiley and Sons. New York.

Subagyo, H., N. Suharta, dan A. B. Siswanto. 2004. Tanah-Tanah Pertanian di Indonesia. Hlm. 2126 dalam A. Adimiharja, L. I. Amien, F. Agus, D. Djaenuddin (Ed). Sumberdaya lahan Indonesia dan pengelolaannya Pusat Penelitian dan Pengembangan Tanah dan Agroklimat, Bogor. 
Tan, K. H. 2010. Principles of Soil Chemistry Fourth Edition. CRC Press Tailor and Francis Group.
Boca Raton. London. New York.

Winarso, S. 2005. Kesuburan Tanah. Gava Media. Yogyakarta. 